\title{
Nutraceutical and Food Preserving Importance of Laetiporus sulphureus ${ }^{\#}$
}

\author{
Sanem Bulam ${ }^{1, a, *}$, Nebahat Şule Üstün ${ }^{2, b}$, Aysun Pekşen ${ }^{3, c}$ \\ ${ }^{I}$ Department of Food Engineering, Faculty of Engineering, Giresun University, Güre Campus, 28200 Giresun, Turkey \\ ${ }^{2}$ Department of Food Engineering, Faculty of Engineering, Ondokuz Mayls University, Kurupelit Campus, 55139 Atakum/Samsun, Turkey \\ ${ }^{3}$ Department of Horticulture, Faculty of Agriculture, Ondokuz Mayls University, Kurupelit Campus, 55139 Atakum/Samsun, Turkey \\ *Corresponding author
}

\begin{tabular}{|c|c|}
\hline A R T I C LE INFO & A B S T R A C T \\
\hline $\begin{array}{l}{ }^{\#} \text { This study was presented as an oral } \\
\text { presentation at the 4th International } \\
\text { Anatolian Agriculture, Food, } \\
\text { Environment and Biology Congress } \\
\text { (Afyonkarahisar, TARGID 2019) } \\
\text { Review Article } \\
\text { Received : } 30 / 05 / 2019 \\
\text { Accepted : } 25 / 07 / 2019\end{array}$ & $\begin{array}{l}\text { Laetiporus sulphureus (Bull.: Fr.) Murr. is popularly known as "sulphur polypore" or "chicken of } \\
\text { the woods" due to its characteristic sulphur yellow coloured polypore's and chicken-like taste and } \\
\text { texture. This edible wild mushroom has been traditionally consumed as a source of nutrition and } \\
\text { folk medicine in Asia and Europe for a long time. The numerous studies have shown that } L \text {. } \\
\text { sulphureus nutritionally provides various key components such as carbohydrate, essential amino } \\
\text { acids and fatty acids, vitamins, minerals, and fibre. Besides, the extracts prepared from fruiting } \\
\text { bodies or mycelia of this mushroom have exhibited a number of medicinal properties such as } \\
\text { immunomodulation, antitumor, anti-inflammatory, antioxidant, antimicrobial, and } \\
\text { antihyperglysemic activities because of their biologically active components such as phenolics, } \\
\text { triterpenes, and polysaccharides. L. sulphureus is also a suitable candidate to be used as a natural } \\
\text { food preserving source. }\end{array}$ \\
\hline
\end{tabular}

Türk Tarım - Gıda Bilim ve Teknoloji Dergisi 7(sp1): 94-100, 2019

\section{Laetiporus sulphureus'un Nutrasötik ve Gıda Koruyucu Olarak Önemi}

\begin{tabular}{l|l}
\hline M A K A L E B İ L G İ S İ & Ö Z \\
\hline $\begin{array}{l}\text { Derleme Makale } \\
\text { Geliş } \quad: 30 / 05 / 2019 \\
\text { Kabul }: 25 / 07 / 2019\end{array}$ & $\begin{array}{l}\text { Laetiporus sulphureus (Bull.: Fr.) Murr., kükürt sarısı poliporları ve tavuk benzeri tadı ve dokusu } \\
\text { nedeniyle "kükürt poliporu" veya "orman tavuğu" olarak bilinmektedir. Bu yenilebilir doğa mantarı, } \\
\text { Asya ve Avrupa'da uzun zamandan beri hem besin kaynağ hem de halk hekimliğinde geleneksel } \\
\text { tıpta kullanılmaktadır. Çalışma sonuçlar L. sulphureus'un karbonhidrat, esansiyel amino asitler ve } \\
\text { yağ asitleri, vitaminler, mineraller ve lif gibi temel besin ögelerini sağladığını göstermektedir. } \\
\text { Ayrıca, mantar veya misellerinden hazırlanan ekstraktlar fenolikler, triterpenler, polisakkaritler gibi } \\
\text { biyolojik aktif bileşenler içerdiklerinden immünomodülasyon, antitümör, anti-enflamatuar, } \\
\text { antioksidan, antimikrobiyal ve antihiperglisemik aktiviteler göstermektedir. L. sulphureus, doğal bir } \\
\text { gida koruyucu olarak kullanılmaya da uygundur. }\end{array}$ \\
$\begin{array}{l}\text { Anahtar Kelimeler: } \\
\text { Orman Tavuğu }\end{array}$ &
\end{tabular}

Laetiporus sulphureus

Besinsel

Tedavi Edici 


\section{Introduction}

Laetiporus sulphureus (Bull.:Fr.) Murrill., also called as Sulfur Tuft, Sulfur Shelf, Chicken-of-the-Woods, and Chicken Mushroom is a member of the class Basidiomycetes (Fomitopsidaceae, Polyporales) (Weber et al., 2004; Radic et al., 2009; Grienke et al., 2014). Laetiporus name is a combination of two words "laeti" (Lat.) and "por" (Lat.) and refers to a hymenial layer and the size of the specifically shaped fruiting bodies. The adjective "sulphureus" (Lat.) originates from the characteristic color of fruiting bodies (Sulkowska-Ziaja et al., 2018). It is a wood-rotting mushroom producing shelfshaped, bracket-like fruiting bodies of pink-orange color, except for the fleshy margin, semicircular hats with a characteristic bright sulfuric-yellow color. It commonly grows in nature from late spring to autumn (Weber et al., 2004; Sulkowska-Ziaja et al., 2018). The remarkable yellowish or orange-colour of $L$. sulphureus contains nonisoprenoid polyene known as laetiporic acid A, B, C and 2dehydro-3-deoxylaetiporic acid $\mathrm{A}$ as the main pigments of natural food colorants (Weber et al., 2004; Davoli et al., 2005). Moreover, the odor of L. sulphureus has been differently described over the years as being more or less pleasant, fungal, and strongly musky to strongly fungoid (Rapior et al., 2000; Wu et al., 2005) that can also be evaluated in food industry. Its fruiting bodies are very large in overlapping clusters of $5-50 \mathrm{~cm}$, annual, spongy to leathery, up to $40 \mathrm{~cm}$ wide, with wet biomass over $40 \mathrm{~kg}$ and tubular hymenopores (Rapior et al., 2000; Luangharn et al., 2014b; Kovács and Vetter, 2015). They colonize in roots, butt, or heartwood of living tree trunks and decaying logs or dead trunks of deciduous species, and more rarely coniferous species (Radic et al., 2009; Luangharn et al., 2014b; Sulkowska-Ziaja et al., 2018). L. sulphureus is a cosmopolitan species and presents on all continents, except Antarctica. It is widely distributed in Asia, Europe and North America from tropical to subtropical zones. In certain parts of these continents, it is considered as a delicacy and can also be used as a substitute for chicken in a vegetarian diet due to its taste as meat of chicken, crab or lobster (Rapior et al., 2000; Ota et al., 2009; Petrović et al., 2013; Grienke et al., 2014). In Turkey, this species has been previously identified in different localities by some researchers (Pekşen and Karaca, 2003; Sesli, 2007; Sesli and Denchev, 2014). Fig. 1 represents photographs of the fruiting bodies of L. sulphureus naturally grown on the roots of rot Prunus avium trunk in a montane village of Keşap, Giresun, Turkey and found at the end of April.
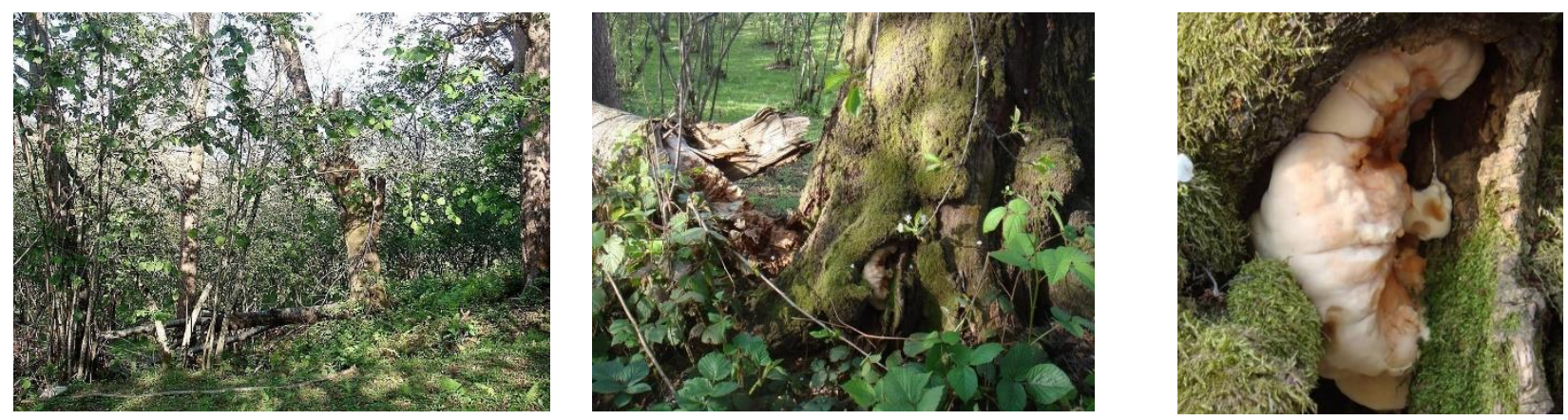

Figure 1 Photos of rot Prunus avium trunk and fruiting body of L. sulphureus (Date: 23.04.2014)

This species is sold in the local markets and consumed in the local cuisine in Turkey as well as worldwide (Pekşen and Karaca, 2000; Pekşen et al., 2016; Mandić et al., 2018). Besides being a food, L. sulphureus fruit bodies have long been used in Asian folk medicine and thought to be capable of regulating the human body, improving health, and defending the body against illnesses (Ying et al., 1987; Zjawiony, 2004). Moreover, the fruiting bodies have been used for the treatment of pyretic diseases, coughs, gastric cancer, and rheumatism in Europe (Rios et al., 2012; Sulkowska-Ziaja et al., 2018). Burning of L. sulphureus is also used as mosquitoes and midges repellent (Ying et al., 1987). Lee et al. (2009) purified and characterized a thermostable extracellular xylanase having potential applications as bioconversion of lignocellulosic materials into fermentative products, improvement of digestibility of animal feedstock, and clarification of juices. Nutritional studies have recently confirmed that it is a sustainable food supply to growing population due to rich content of carbohydrate, protein, minerals, vitamins, polyunsaturated fatty acids, and fibre. In recent years, several primary and secondary biologically active components and extracts have been prepared from fruiting bodies or mycelia of $L$. sulphureus exhibiting immunomodulation, antitumor, anticoagulation, antioxidant, antibacterial, antifungal, insecticidal, anti-ulcer, insulin tropic, anti-HIV, and cytostatic activities (Grienke et al., 2014; Khatua et al., 2017; Sulkowska-Ziaja et al., 2018). Previous studies on this species have revealed many interesting metabolites that can be utilized in biotechnological studies about medicine and food industries on larger scale. These compounds include laetiporic acids, polysaccharides and alkali-soluble polysaccharides, fatty acids, amino acids, and $\alpha-(1 \rightarrow 3)$-glucans (Luangharn et al., 2014a; Khatua et al., 2017). In some other studies, L. sulphureus was cultivated as fruiting bodies and hyphal mycelium on a larger scale in laboratory which may open way to commercial production (Agafonova et al., 2007; Pleszczyńska et al., 2013; Luangharn et al., 2014a; 2014b). In addition, food industry has started to search for novel natural substances to prolong the shelf life of food products. Regarding food-preserving properties of $L$. sulphureus, a number of successful antifungal studies against Aspergillus flavus in tomato paste kept at room temperature $\left(25^{\circ} \mathrm{C}\right)$ for 15 days (Petrović et al., 2013) and chicken pate stored at $+4^{\circ} \mathrm{C}$ for 21 days (Petrović et al., 
2014a) with the addition of L. sulphureus methanolic extract have been recently carried out. Thus, the species is considered as a natural resource of nourishment and food preservation as well as drug therapy and consequently it has increasingly become popular in scientific world.

However, gastrointestinal problems, occurrence of severe adverse effects including allergic reactions, vomiting and fever have been previously reported (Jordan, 1995; Watling, 1997). L. sulphureus consumption has also been reported to cause visual hallucinations and ataxia. Gas chromatographic analysis of the mushroom was negative for known hallucinogens. In that particular case, the toxic effects were attributed to a combination of factors, including the patient's age, the amount ingested, and the fact that it was eaten raw (Appleton et al., 1988). This review focuses on the nutrients and constituents of $L$. sulphureus and their biological activities as well as its food preserving property.

\section{Nutritional Value of L. sulphureus}

The water content in L. sulphureus ranged from 66.67 to $72.69 \%$ (Palazzolo et al., 2012; Saha et al., 2014) and carbohydrate content from 64.90 to $74.47 \mathrm{~g} / 100 \mathrm{~g} \mathrm{dw}$ (Ayaz et al., 2011; Petrović et al., 2014a; Kovács and Vetter, 2015). Olennikov et al. (2008) detected the composition of carbohydrates as mannite, free carbohydrates, water-soluble polysaccharides (WSPS), base-soluble polysaccharides (BSPS), and chitin. Free sugars identified by HPLC as trehalose was the dominant sugar (4 g/100 g dw), followed by mannitol (3.54 g/100 g $\mathrm{dw})$, while fructose was present in minor amount $(0.46$ g/100 g dw) (Petrović et al., 2014a). Turfan et al. (2018) detected total soluble carbohydrates, glucose, fructose, and sucrose as 266.82, 40.49, 6.31 and $0.32 \mathrm{mg} / \mathrm{g}$, respectively. Crude protein contents of L. sulphureus varied considerably (10.61-21.00 g/100 g dw) (Ayaz et al., 2011; Petrović et al., 2014a; Saha et al., 2014; Kovács and Vetter, 2015). Agafonova et al. (2007) reported essential amino acids of arginine, histidine, isoleucine, leucine, lysine, methionine, threonine, and tryptophan as $0.47,0.40,0.11$, $0.52,0.28,0.17,0.20,0.33 \%$ and $0.38,0.58,0.13,0.30$, $0.32,0.18,0.24,0.79 \%$ for the fruiting bodies of $L$. sulphureus strains LS-BG-0804 and LS-UK-0704, respectively. Turfan et al. (2018) found total soluble protein and total free amino acid amounts of L. sulphureus as 83.27 and $3.63 \mathrm{mg} / \mathrm{g}$, respectively. The fat content in $L$. sulphureus ranged from 2.96 to $4.50 \mathrm{~g} / 100 \mathrm{~g} \mathrm{dw}$ (Palazzolo et al., 2012; Luangharn et al., 2014a; Petrović et al., 2014a; Saha et al., 2014; Kovács and Vetter, 2015). Sinanoglou et al. (2015) determined that triglycerides were the most abundant in the neutral lipid fraction, whereas phosphatidylcholine in phospholipids. Total lipids were found to contain high degree of unsaturated fatty acids (UFA/SFA>3.4) and C18:2 $\omega-6, \mathrm{C} 18: 1 \omega-9$, and C16:0 fatty acids dominated. In a study about the lipid composition of two strains, unsaturated fatty acids were in higher amounts and linoleic acid was dominant (47.50 and 48.19\%, respectively) followed by oleic acid (19.33 and $19.43 \%$, respectively) (Agafonova et al., 2007). But, according to Palazzolo et al. (2012), the dominant fatty acid was oleic acid (52.35\%), followed by linoleic acid (20.62\%). Petrović et al. (2014a) reported linoleic acid (63.27\%) as the most abundant fatty acid, followed by oleic acid (14.52\%) and palmitic acid (11.68\%). Bengu (2019) determined high amounts of linoleic $(7.73 \%)$, stearic (28.55\%), palmitic (28.60\%), and oleic acids (33.94\%) in L. sulphureus. Ericsson and Ivonne (2009) analysed the sterol composition of this mushroom and identified cerevisterol and ergosterol peroxide in addition to conventional sterols. Energy content of L. sulphureus was found as 341.06-375.62 kcal/100 g dw (Ayaz et al., 2011; Petrović et al., 2014a; Kovács and Vetter, 2015). Fibre content of L. sulphureus ranged from 4.12 to $6.43 \% \mathrm{dw}$ (Luangharn et al., 2014a; Saha et al., 2014; Kovács and Vetter, 2015). Ash content in L. sulphureus was found to be low and varied from 4.00 to $9.03 \mathrm{~g} / 100 \mathrm{~g} \mathrm{dw}$ (Ayaz et al., 2011; Petrović et al., 2014a; Kovács and Vetter, 2015). The macro (Ca, P, Mg, Na, K, etc.) and micro elements (Fe, $\mathrm{Zn}, \mathrm{Mn}, \mathrm{Cu}, \mathrm{Si}, \mathrm{Mo}, \mathrm{B}$, etc.) of wild and cultivated $L$. sulphureus considerably differed due to habitat, geographical location and collection time of the mushroom samples, cultivation methods and analysis methods (Agafonova et al., 2007; Ayaz et al., 2011; Durkan et al., 2011; Palazzolo et al., 2012; Luangharn et al., 2014a; Saha et al., 2014; Kovács and Vetter, 2015; Turfan et al., 2018; Bengu, 2019). Petrović et al. (2014a) indicated the tocopherols in the order of $\alpha$-tocopherol $>\gamma$-tocopherol $>\delta$ tocopherol. Palazzolo et al. (2012) determined niacin (4.2 $\mathrm{mg} \%)$, pantotenic acid $(0.464 \mathrm{mg} \%)$, biotin $(4.8 \mu \mathrm{g} \%), \mathrm{B}_{12}$ $(0.98 \mu \mathrm{g} \%)$, and $\mathrm{D}_{3}(0.75 \mu \mathrm{g} \%)$. Malic acid, ascorbic acid, citric acid, tartaric acid, malonic acid, succinic acid, oxalic acid, fumaric acid, and quinic acid have been previously detected in both wild and cultivated strains of L. sulphureus (Olennikov et al., 2008; Ayaz et al., 2011; Petrović et al., 2014a).

\section{Bioactive Compounds of $L$. sulphureus and Their Pharmacological Activities}

L. sulphureus contains N-methylated tyramine derivatives (Rapior et al., 2000), polysaccharides, lanostane triterpenoids, laetiporic acids, and other metabolites (Alquini et al., 2004; Weber et al., 2004; Davoli et al., 2005; Radic et al., 2009; Luangharn et al., 2014a; Khatua et al., 2017; Sulkowska-Ziaja et al., 2018) that are significantly correlated with various bioactivities.

The most important medically active primary metabolites of L. sulphureus comprise high-molecular weight compounds as polysaccharides, proteins, and polysaccharide-protein complexes. In addition, some pigments and nucleic acids have also been described to be biologically active (Grienke et al., 2014). L. sulphureus fruit bodies are a rich source of $\alpha-(1,3)$-D-glucans and their cell wall contains up to $88 \%(\mathrm{dw})$ of this glucan, whereas other mushrooms contain only 9-46\% (Wiater et al., 2012). Antioxidant effects were reported for water-soluble and alkali-soluble polysaccharides extracted from $L$. sulphureus (Olennikov et al., 2009a; 2009b; Klaus et al., 2013). Olennikov et al. (2009a) isolated Laetiporan A as the major $56-\mathrm{kDa}$ polysaccharide, that was found to be comprised of a $\beta$-1,3-glucan containing mannose, galactose, fucose, xylose, and rhamnose residues at position C-6. The pure polysaccharide prevented liver lesion in toxic hepatitis model by executing strong antioxidant effect on lipid peroxidation. Crude 
extracellular polysaccharides produced from a submerged mycelial culture of L. sulphureus provoked a hypoglycaemia effect in streptozotocin-induced diabetic rats, indicating that these substances could be useful in diabetes mellitus treatment (Hwang and Yun, 2010). Bioactivities related to bioactive proteins include antitumor, antiviral, antimicrobial, antioxidative, and immunomodulatory properties (Kang et al., 1982; Xu et al., 2011). Mushroom proteins can be structurally categorized as classical proteins/peptides (including enzymes), or lectins, i.e. carbohydrate-binding proteins. Konska et al. (1994) characterized lectins from L. sulphureus in detail. A protein-polysaccharide fraction from fruit bodies of $L$. sulphureus consisting of $84 \%$ polysaccharide and 5\% protein exerted antitumor activity against sarcoma 180 in mice (Kang et al., 1982). Laetiporic acids, i.e. noncarotenoid polyene pigments, identified in L. sulphureus fruiting bodies have shown well-known antioxidant properties and their high stability may also render them attractive as food dye (Weber et al., 2004; Davoli et al., 2005).

About $75 \%$ of bioactive secondary metabolites are composed of triterpenoids (acids, esters and lactones, alcohols, ethers and peroxides, aldehydes and ketones, glycosidic triterpenes, miscellaneous triterpenes) with different structures, whereas other secondary metabolite classes are produced to a lesser extent. The second largest group of secondary metabolites $(\sim 14 \%)$ is composed of organic acids. L. sulphureus also contains other compounds belonging to different chemical classes, i.e. benzofurans, flavonoids, coumarins, and N-containing compounds (Grienke et al., 2014). In general, volatile components of L. sulphureus can be categorized as (i) fatty acids and methyl-branched carboxylic acids, (ii) C8 compounds and benzoic volatiles, and (iii) volatile amines (Rapior et al., 2000; Wu et al., 2005; Petrović et al., 2013). More than 40 major volatiles were identified by (HR) GC$\mathrm{MS}$ and gas chromatography-olfactometry (GC-O) methods. However, because of difficulties in assaying such compounds, no biological activity has been linked to these volatile components (Grienke et al., 2014). The primarily EtOH and $\mathrm{MeOH}$ extracts of L. sulphureus were evaluated for cytotoxic, antioxidant and antimicrobial effects (Keller et al., 2002; Karaman et al., 2010, 2009; Ozen et al., 2011; Turfan et al., 2018). Orhan and Üstün (2011) evaluated the acetylcholinesterase (AChE) inhibitory activities of $L$. sulphureus and possible use of its fruiting bodies in the treatment of Alzheimer's disease. Six lanostane-type triterpene acids from $L$. sulphureus were assayed in an MTT assay for their apoptotic potential against HL-60 cells (human myeloid leukaemia cells) and acetylated triterpenes showed more potent effects than non-acetylated derivatives (León et al., 2004). Lear et al. (2009) identified (7)-laetirobin benzofuran from $L$. sulphureus as a cytostatic compound with rapid cell entry. Ergosterol peroxide having potential cytotoxic activity was isolated from L. sulphureus (Krzyczkowski et al., 2009). Fan et al. (2014) isolated three mycophenolic acid derivatives from L. sulphureus. Among them, 6- $((2 E, 6 E)-3,7,11-$ trimethyldedoca-2, 6, 10-trienyl)-5, 7-dihydroxy-4methylphtanlan-1-one exhibited moderate cytotoxicity against HL-60, SMMC-7721, A-549 and MCF-7 cells with $\mathrm{IC}_{50}$ values of $39.1,31.1,27.4$, and $35.7 \mu \mathrm{mol} / \mathrm{L}$, respectively. He et al. (2015) obtained seven new drimanetype sesquiterpenoids, sulphureuines $\mathrm{B}-\mathrm{H}$, together with four known compounds from cultures of mushroom $L$. sulphureus and tested for their cytotoxicities against five human cancer cell lines. As a result, compound 10 showed potent cytotoxic activity against HL-60, SMMC-721, A549 , SW-480, with $\mathrm{IC}_{50}$ values of $37.5,14.8,15.6$, and 36.1 $\mu \mathrm{M}$, respectively. Keskin et al. (2017) determined that $10 \%$ cytotoxicity was observed at $0.25 \mathrm{mg} / \mathrm{ml}$ dosage used in MCF-7 cell line. At all dosages used, viability rates were increased in L929 Fibroblast cell lines. In addition, apoptotic and necrotic effects were observed in the samples.

Turfan et al. (2018) found total phenolics and total flavonoids of L. sulphureus as 28.68 and $12.81 \mathrm{mg} / \mathrm{g}$, respectively. In the study of Turkoglu et al. (2007), the fraction exhibited dose dependent DPPH radical scavenging ability as it inhibited $14,26,55$, and $86 \%$ at the concentrations of $100,200,400$ and $800 \mu \mathrm{g} / \mathrm{ml}$, respectively. While in $\beta$-carotene/linoleic acid system, the ethanolic extract showed $57.4 \%$ of inhibition at $80 \mu \mathrm{g} / \mathrm{ml}$ concentration that increased to $82.2 \%$ at $160 \mu \mathrm{g} / \mathrm{ml}$ concentration. Klaus et al. (2013) found that, the hot alkali extract of L. sulphureus was the most effective in the DPPH radical scavenging, reducing power, and ferrous ion-chelating ability. Very strong correlation was also observed between $\alpha$-glucan content ( $17.3 \mathrm{~g} / 100 \mathrm{~g} \mathrm{dw})$ and the $\mathrm{EC}_{50}$ values of these antioxidant activity assays as 0.5 , 4.0 and $1.5 \mathrm{mg} / \mathrm{ml}$, respectively. In another study, the extracts of $L$. sulphureus fruiting bodies and mycelia had 0.68 and $4.92 \mathrm{mg} / \mathrm{ml} \mathrm{EC}_{50}$ values of $\mathrm{DPPH}$ radical scavenging activity, respectively. In the same study, total phenolics contents of L. sulphureus fruiting bodies and mycelia extracts were 12.14 and $6.85 \mathrm{mg} \mathrm{GAE} / \mathrm{g}$, respectively (Prasad et al., 2015). Popa et al. (2016) reported that the highest total phenols amount $(283.9 \mathrm{mg}$ GAE/100g) was found in fruiting bodies extract among the dried fruiting bodies, dried mycelia broth, and mycelia-free broth submerged cultures. In the pharmacognostic standardization study of Acharya et al. (2016), the fraction showed potent activity in superoxide radical scavenging, DPPH radical scavenging, chelating ability of ferrous ion, reducing power, and total antioxidant assays where $\mathrm{EC}_{50}$ values ranged from 0.11 to $1.38 \mathrm{mg} / \mathrm{ml}$ concentration and the fraction was composed of different bioactive compounds such as phenolics, flavonoids, carotenoids, and ascorbic acid. Beauvericin, an antimicrobial secondary metabolite including a cyclodepsipeptide, has been detected in L. sulphureus. Moreover, it has also possessed insecticidal and nematocidal activity (Zjawiony, 2004). In another study, results showed that the ethanol extract had a narrow antibacterial spectrum against Gram (-) bacteria, though strongly inhibited growth of Gram (+) bacteria examined. However, the fraction did not show any activity against Klebsiella pneumoniae at the evaluated concentrations (Turkoglu et al. 2007). In a study, results indicated that hexane extracts possessed better antifungal and slightly better antibacterial activity compared to chloroform extracts though both were less active than the commercial antimicrobial agents (Sinanoglou et al., 2015). Zhang et al. (2018) determined that antibacterial activity of ethanol, petroleum ether, and ethyl acetate extracts from $L$. sulphureus was better than antifungal activity. Gasecka et 
al. (2018) reported ergosterol content of L. sulphureus having antioxidant activity as $0.540 \mathrm{mg} / \mathrm{g} \mathrm{dm}$. Petrović et al. (2014b) prepared aqueous, ethanol, and methanol extracts obtained after application of classical and ultrasound-assisted extraction methods. All fractions presented high potentials to inhibit growth of microorganisms while extracts obtained by ultrasound technique were proved to be more potent than that of classical extract. In some cases, the activity of methanolic and ethanolic formulations prepared by ultrasound technique exceeded that of commercial antibiotics. Besides antioxidant, antimicrobial, cytotoxic, and anticancer studies, some researches on other medicinal attributes of both L. sulphureus derived extracts and individual compounds, such as anti-HIV (Mlinaric et al., 2005), antimalaria, anti-ulcer, hepatoprotective (Sun et al., 2014), anti-inflammation (Saba et al., 2015), immunomodulatory (Wang et al., 2019), hypolipidemic, anti-diabetic, and antithrombin activities have been previously reported (Radic et al., 2009; Grienke et al., 2014; Khatua et al., 2017; Sulkowska-Ziaja et al., 2018).

\section{Food Preserving Studies}

The growth of microorganisms and free-radical production are the two basic reasons of food spoilage, so the natural sources of antioxidant and antimicrobial compounds should be considered important. Being a mushroom that can be easily found, recognized in nature and easily cultured, L.sulphureus is a suitable material for the researches. Therefore, there have been some studies in the literature conducted on the use of L. sulphureus as a natural food preserving agent that could bring functional preservations due to its determined antimicrobial and antioxidant properties. In a study realized by Petrović et al. (2013), antimicrobial activity of methanol, acetone, and dichloromethane extracts from $L$. sulphureus in combination with and without $0.01 \mathrm{M}$ food additive, potassium disulfite (E224) have been in vitro investigated against eight bacterial and eight fungal species, and methanol extract of $L$. sulphureus showing the best inhibitory activity with MIC value of $20 \mathrm{mg} / \mathrm{ml}$ was also studied for in situ control of Aspergillus flavus in tomato paste usually considered as semi-finished food. A. flavus has been able to produce dangerous mycotoxin of aflatoxin in foods (Kalantari et al., 2012), so it was important to assess the antifungal activity of this mushroom's extract. In situ results demonstrated complete inhibition of $A$. flavus growth in tomato paste after 15 days of the treatment at $25{ }^{\circ} \mathrm{C}$ with the concentrations of $15 \mathrm{mg} / \mathrm{ml}$ of $L$. sulphureus methanol extract. In another study, Petrović et al. (2014a) determined the nutritional value, bioactive compounds, in vitro antioxidant, antitumor, and antimicrobial properties of L. sulphureus. Moreover, a suitable model system with chicken pate was developed to test the in situ antifungal preserving properties of $L$. sulphureus methanolic extract against A. flavus. The inhibition of $A$. flavus growth in chicken pate was dose dependent and higher concentrations of $L$. sulphureus extract $(3.56-5.49 \mathrm{mg} / \mathrm{ml})$ completely inhibited mycelial growth after 21 days storage at $4{ }^{\circ} \mathrm{C}$. The prevention of mould development is highly recommendable, from the slaughtering of animals to the packaging of the final product (Mizakova et al., 2002). Because of consumers' awareness, food products preserved with natural additives are becoming more popular (Hooley and Patel, 2005). When choosing a natural antioxidant for the purposes of prolonging the shelf life of food, the impact on the sensory and taste qualities should also be taken into account. $L$. sulphureus with proven antimicrobial and antioxidant properties can functionally preserve meat products, affect their taste in a positive way, and make them acceptable to the customer (Petrović et al., 2014a).

\section{Conclusion}

L. sulphureus has revealed presence of essential nutrients and can be used in low-calorie diets. Various studies have also provided evidences that L. sulphureus contains several bioactive components with outstanding properties to treat different types of disorders. However, most of the researches based on in vitro studies and few in vivo experimentations were only performed. Therefore, in future research, clinical studies are essential to confirm the safety, bioavailability and the effects of these mushroom derived compounds. In addition, new collaborated biotechnological studies must be conducted to be able to use L. sulphureus as health-promoting functional food as well as natural food additive prolonging shelf life of the foods and food safe colorant and odor compound in food industry.

\section{References}

Acharya K, Ghosh S, Khatua S, Mitra P. 2016. Pharmacognostic standardization and antioxidant capacity of an edible mushroom Laetiporus sulphureus. J Verbrauch Lebensm 11(1): 33-42.

Agafonova SV, Olennikov DN, Borovskii GB, Penzina TA. 2007. Chemical composition of fruiting bodies from two strains of Laetiporus sulphureus. Chem Nat Compd 43(6): 687-688.

Alquini G, Carbonero ER, Rosado FR, Cosentino C, Iacomini M. 2004. Polysaccharides from the fruit bodies of the basidiomycete Laetiporus sulphureus (Bull.:Fr.) Murr. FEMS Microbiol Lett 230: 47-52.

Appleton RE, Jan J, Kroeger PD. 1988. Laetiporus sulphureus causing visual hallucinations and ataxia in a child. Can Med Assoc J 139: 48-49.

Ayaz FA, Torun H, Özel A, Col M, Duran C, Sesli E, Colak A. 2011. Nutritional value of some wild edible mushrooms from Black Sea Region (Turkey). Turk J Bioch 36(3): 213-221.

Bengu AS. 2019. Some elements and fatty acid profiles of three different wild edible mushrooms from Tokat province in Turkey. Progress in Nutrition 21(1): 189-193.

Davoli P, Mucci A, Schenetti L, Weber RWS. 2005. Laetiporic acids, a family of non-carotenoid polyene pigments from fruit-bodies and liquid cultures of Laetiporus sulphureus (Polyporales, Fungi). Phytochem 66:817-823.

Durkan N, Ugulu I, Unver MC, Dogan Y, Baslar S. 2011. Concentrations of trace elements aluminum, boron, cobalt and tin in various wild edible mushroom species from Buyuk Menderes River Basin of Turkey by ICP-OES. Trace Elem Electroly 28(4): 242-248.

Ericsson DCB, Ivonne JNR. 2009. Sterol composition of the macromycete fungus Laetiporus sulphureus. Chem Nat Compd 45(2): 193-196.

Fan QY, Yin X, Li ZH, Li Y, Liu JK, Feng T, Zhao BH. 2014. Mycophenolic acid derivatives from cultures of the mushroom Laetiporus sulphureus. Chin J Nat Med 12(9): 685-688 
Gasecka M, Siwulski M, Mleczek M. 2018. Evaluation of bioactive compounds content and antioxidant properties of soil-growing and wood-growing edible mushrooms. J Food Process Preserv 42: 1-10.

Grienke U, Zöll M, Peintner U, Rollinger JM. 2014. European medicinal polypores- A modern view on traditional uses. J Ethnopharmacol 154: 564-583.

He JB, Taob J, Miao XS, Buc W, Zhanga S, Donga ZJ, Li ZH, Feng T, Liu JK. 2015. Seven new drimane-type sesquiterpenoids from cultures of fungus Laetiporus sulphureus. Fitoterapia 102: 1-6.

Hooley RA, Patel D. 2005. Improvement in shelf-life and safety of perishable foods by plant essential oils and smoke antimicrobials, Food Microbiol 22: 273-292.

Hwang HS, Yun JW. 2010. Hypoglycemic effect of polysaccharides produced by submerged mycelial culture of Laetiporus sulphureus on streptozotocin-induced diabetic rats. Biotechnol Bioprocess Eng 15: 173-181.

Jordan M. 1995. Evidence of severe allergic reactions to Laetiporus sulphureus. Mycologist 9: 157-158.

Kalantari F, Barzegar M, Hamidi-Esfahani Z. 2012. Control of Aspergillus flavus growth in tomato paste by Cinnamomum zeylanicum and Origanum vulgare L. essential oils. Int Schol and Sci Res \& Innova (WASET) 6(6): 321-325.

Kang C, Lee C, Chung K, Choi E, Kim B. 1982. An antitumor component of Laetiporus sulphureus and its immunostimulating activity. Arch Pharm Res 5: 39-43.

Karaman M, Mimica-Dukic N, Knezevic P, Svircev Z, Matavuly M. 2009. Antibacterial properties of selected lignicolous mushrooms and fungi from Northern Serbia. Int J Med Mush 11: 269-279.

Karaman M, Jovin E, Malbasa R, Matavuly M, Popovic M. 2010. Medicinal and edible lignicolous fungi as natural sources of antioxidative and antibacterial agents. Phytother Res 24: 1473-1481.

Keller C, Maillard M, Keller J, Hostettmann K. 2002. Screening of European fungi for antibacterial, antifungal, larvicidal, molluscicidal, antioxidant and free radical scavenging activities and subsequent isolation of bioactive compounds. Pharma Biology 40: 518-525.

Keskin A, Güler P, Türk M. 2017. Laetiporus sulphureus (Bull.) Murrill'un sitotoksite, apoptik ve nekrotik etkileri. Life Sci (NWSALS) 12(4): 64-71.

Khatua S, Ghosh S, Acharya K. 2017. Laetiporus sulphureus (Bull.: Fr.) Murr. as food as medicine. Pharmacog J 9(6): 115.

Klaus A, Kozarski M, Niksic M, Jakovljevic D, Todorovic N, Stefanoska I, Van Griensven LJLD. 2013. The edible mushroom Laetiporus sulphureus as potential source of natural antioxidants. Int J Food Sci Nutr 64(5): 599-610.

Konska G, Guillot J, Dusser M, Damez M, Botton B. 1994. Isolation and characterization of an $\mathrm{N}$-acetyllactosaminebinding lectin from a mushroom Laetiporus sulfureus. J Biochem 116: 519-523.

Kovács D, Vetter J. 2015. Chemical composition of the mushroom Laetiporus sulphureus (Bull.) Murill. Acta Aliment 44(1): 104-110.

Krzyczkowski W, Malinowska E, Suchocki P, Kleps J, Olejnik M, Herold F. 2009. Isolation and quantitative determination of ergosterol peroxide in various edible mushroom species. Food Chem 113: 351-355.

Lear MJ, Simon O, Foley TL, Burkart MD, Baiga TJ, Noel JP, DiPasquale AG, Rheingold AL, La Clair JJ. 2009. Laetirobin from the parasitic growth of Laetiporus sulphureus on Robinia pseudoacacia. J Nat Prod 72: 1980-1987.

Lee JW, Park JY, Kwon M, Choi IG. 2009. Purification and characterization of a thermostable xylanase from the brownrot fungus Laetiporus sulphureus. J Biosci Bioeng 107(1): 33-37.
León F, Quintana J, Rivera A, Estevez F, Bermejo J. 2004. Lanostanoid triterpenes from Laetiporus sulphureus and apoptosis induction on HL-60 human myeloid leukemia cells. J Nat Prod 67: 2008-2011.

Luangharn T, Hyde KD, Chukeatirote E. 2014a. Proximate analysis and mineral content of Laetiporus sulphureus strain MFLUCC 12-0546 from Northern Thailand. Chiang Mai J Sci 41(4): 765-770.

Luangharn T, Karunarathna SC, Hyde KD, Chukeatirote E. 2014b. Optimal conditions of mycelia growth of Laetiporus sulphureus sensu lato. Mycology 5(4): 221-227.

Mandić R, Adžemović M, Marjanović Ž. 2018. Conservation and trade of wild edible mushrooms of Serbia-history, state of the art and perspectives. Nat Conserv 25: 31-53.

Mizakova A, Pipova M, Turek P. 2002. The occurrence of moulds in fermented raw meat products. Czech J Food Sci 20: 89-94.

Mlinaric A, Kac J, Pohleven H. 2005. Screening of selected wood-damaging fungi for the HIV-1 reverse transcriptase inhibitors. Acta Pharm, 55: 69-79.

Olennikov DN, Agafonova SV, Nazarova AV, Borovskii GB, Penzina TA. 2008. Organic acids and carbohydrates from Laetiporus sulphureus fruiting bodies. Chem Nat Compd 44(6): 762-763.

Olennikov DN, Agafonova SV, Borovskii GB, Penzina TA, Rokhin AV. 2009a. Alkali-soluble polysaccharides of Laetiporus sulphureus (Bull.: Fr.) Murr fruit bodies. Appl Biochem Microbiol 45: 626-630.

Olennikov DN, Agafonova S., Borovskii GB, Penzina TA, Rokhin AV. 2009b. Water-soluble endopolysaccharides from the fruiting bodies of Laetiporus sulphureus (Bull.: Fr.) Murr. Appl Biochem Microbiol 45: 536-543.

Orhan I, Üstün O. 2011. Determination of total phenol content, antioxidant activity and acetylcholinesterase inhibition in selected mushrooms from Turkey. J Food Compos Anal 24: 386-390.

Ota Y, Hattori T, Banik MT, Hagedorn G, Sawako K, Sotome T, Abe Y. 2009. The genus Laetiporus (Basidiomycota, Polyporales) in East Asia. Mycol Res 113: 1283-1300.

Ozen T, Darcan C, Aktop O, Turkekul I. 2011. Screening of antioxidant, antimicrobial activities and chemical contents of edible mushrooms wildly grown in the Black Sea Region of Turkey. Comb Chem High Throughput Screen 14: 72-84.

Palazzolo E, Gargano ML, Venturella G. 2012. The nutritional composition of selected wild edible mushrooms from Sicily (Southern Italy). Int J Food Sci Nutr 63(1): 79-83.

Pekşen A, Karaca HG. 2000. Samsun ili ve çevresinde saptanan yenilebilir mantar türleri ve bunların tüketim potansiyeli. Türkiye VI. Yemeklik Mantar Kongresi Bildirileri. Bergama, İzmir, Turkey. 20-22 Eylül 2000, s. 100-111.

Pekşen A, Karaca G. 2003. Macrofungi of Samsun province. Turk J Bot 27: 173-184.

Pekşen A, Bulam S, Üstün NŞ. 2016. Edible wild mushrooms sold in Giresun local markets. In: 1st International Mediterranean Science and Engineering Congress (IMSEC 2016) Proceedings Book. Adana, Turkey. 26-28 October 2016. pp. 3358-3362.

Petrović J, Glamočlija J, Stojković DS, Ćirić A, Nikolić M, Bukvički D, Guerzoni ME, Soković MD. 2013. Laetiporus sulphureus, edible mushroom from Serbia: investigation on volatile compounds, in vitro antimicrobial activity and in situ control of Aspergillus flavus in tomato paste. Food Chem Toxicol 59: 297-302.

Petrović J, Stojković D, Reis FS, Barros L, Glamočlija J, Ćirić A, Ferreira ICFR, Soković M. 2014a. Study on chemical, bioactive and food preserving properties of Laetiporus sulphureus (Bull.: Fr.) Murr. Food Funct 5: 1441-1451.

Petrović J, Papandreou M, Glamočlija J, Ćirić A, Baskakis C, Proestos C, Lamari F, Zoumpoulakis P, Soković M. 2014b. Different extraction methodologies and their influence on the bioactivity of the wild edible mushroom Laetiporus sulphureus (Bull.) Murrill. Food Funct 5: 2948-2960. 
Pleszczyńska M, Wiater A, Siwulski M, Szczodrak J. 2013. Successful large-scale production of fruiting bodies of Laetiporus sulphureus (Bull.: Fr.) Murrill on an artificial substrate. World J Microbial Biotechnol 29: 753-758.

Popa G, Cornea CP, Luta G, Gherghina E, Israel-Roming F, Bubueanu C, Toma R. 2016. Antioxidant and antimicrobial properties of Laetiporus sulphureus (Bull.) Murrill. AgroLife Sci J 5(1): 168-173.

Prasad R, Varshney VK, Harsh NSK, Kumar M. 2015. Antioxidant capacity and total phenolics content of the fruiting bodies and submerged cultured mycelia of sixteen higher Basidiomycetes mushrooms from India. Int $\mathrm{J}$ Med Mushrooms 17(10): 933-941.

Radic N, Injac R, Strukelj B. 2009. Sulphur tuft culinarymedicinal mushroom, Laetiporus sulphureus (Bull.:Fr.) Murrill (Aphyllophoromycetideae): Bioactive compounds and pharmaceutical effects (review). Int J Med Mushrooms 11: 103-116.

Rapior S, Konska G, Guillot J, Andary C, Bessiere JM. 2000. Volatile composition of Laetiporus sulphureus. Cryptogamie Mycol 21(1): 67-72.

Rios JL, Andujar I, Recio MC, Giner RM. 2012. Lanostanoids from fungi: a group of potential anticancer compounds. J Nat Prod 75: 2016-2044.

Saba E, Son Y, Jeon BR, Kim SE, Lee IK, Yun BS, Rhee MH. 2015. Acetyl eburicoic acid from Laetiporus sulphureus var. miniatus suppresses inflammation in murine macrophage Raw 264.7 Cells. Mycobiology 43(2): 131-136.

Saha D, Sundriyal M, Sundriyal RC. 2014. Diversity of food composition and nutritive analysis of edible wild plants in a multi-ethnic tribal land, Northeast India; an important facet for food supply. Indian J Tradit Knowl 13(4): 698-705.

Sesli E. 2007. Preliminary checklist of the macromycetes of the East and Middle Black Sea Regions of Turkey. Mycotaxon 99: 71-74.

Sesli E, Denchev CM. 2014. Checklists of the myxomycetes, larger ascomycetes, and larger basidiomycetes in Turkey. 6th edn. Mycotaxon Checklists Online (http://www.mycotaxon.com /resources/checklists/sesli-v106-checklist.pdf): 1-136.

Sinanoglou VJ, Zoumpoulakis P, Heropoulos G, Proestos C, Ciric A, Petrović J, Glamoclija J, Sokovic M. 2015. Lipid and fatty acid profile of the edible fungus Laetiporus sulphurous. Antifungal and antibacterial properties. J Food Sci Technol 52(6): 3264-3272.
Sulkowska-Ziaja K, Muszyńska B, Gawalska A, Sałaciak K. 2018. Laetiporus sulphureus- chemical composition and medicinal value. Acta Sci Pol Hortorum Cultus 17(1): 89-98.

Sun W, He H, Wang J, Wu L, Cheng F, Deng Z. 2014. The main components analysis of Laetiporus sulphureu crude extract and its hepatoprotective effect on carbon tetrachlorideinduced hepatic fibrosis in rats. Appl Mechanics Materials 568-570: 1934-1939.

Turfan N, Pekşen A, Kibar B, Ünal S. 2018. Determination of nutritional and bioactive properties in some selected wild growing and cultivated mushrooms from Turkey. Acta Sci Pol Hortorum Cultus 17(3): 57-72.

Turkoglu A, Duru ME, Mercan N, Kivrak I, Gezer K. 2007. Antioxidant and antimicrobial activities of Laetiporus sulphureus (Bull.) Murrill. Food Chem 101: 267-273.

Wang Y, Zhang Y, Shao J, Wua B, Li B. 2019. Potential immunomodulatory activities of a lectin from the mushroom Latiporus sulphureus. Int J Biological Macromolec, 130: 399-406.

Watling R. 1997. Poisoning by fungi: Interesting cases. Mycologist 11(3): 101-101.

Weber RWS, Mucci A, Davoli P. 2004. Laetiporic acid, a new polyene pigment from the wood-rotting basidiomycete Laetiporus sulphureus (Polyporales, Fungi). Tetrahedron Lett 45: 1075-1078.

Wiater A, Pleszczynska M, Szczodrak J, Janusz G. 2012. Comparative studies on the induction of Trichoderma harzianum mutanase by $\alpha$-(1,3)-glucan-rich fruiting bodies and mycelia of Laetiporus sulphureus. Int J Molecular Sci 13: 9584-9598.

Wu SM, Zorn H, Krings U, Berger RG. 2005. Characteristic volatiles from young and aged fruiting of wild Polyporus sulfureus (Bull.: Fr.) Fr. J Agric Food Chem 53: 4524-4528.

Xu X, Yan H, Chen J, Zhang X. 2011. Bioactive proteins from mushrooms. Biotechnol Adv 29: 667-674.

Ying J, Mao X, Ma Q, Zong Y, Wen H. 1987. Icones of medical fungi from China. Beijing. Science Press. ISBN: 7030001958.

Zhang J, Lv J, Zhao L, Shui X, Wang L. 2018. Antioxidant and antimicrobial activities and chemical composition of submerged cultivated mycelia of Laetiporus sulphureus. Chem Nat Compounds 54(6): 1187-1188.

Zjawiony JK. 2004. Biologically active compounds from Aphyllophorales (Polypore) fungi. J Nat Prod 67: 300-310. 